\title{
Social Work Education in Indonesia: History and Current Situation
}

\author{
Adi Fahrudin ${ }^{1, *}$, Husmiati Yusuf ${ }^{2}$ \\ ${ }^{1}$ Department of Social Welfare, Faculty of Social and Political Sciences, University of Muhammadiyah Jakarta, Indonesia \\ ${ }^{2}$ Center for Social Welfare Research and Development, Ministry of Social Affair, Jakarta, Indonesia \\ *Corresponding Author: fahradi@gmail.com
}

\begin{abstract}
This paper gives an overview of the brief history and current situation of social work education in Indonesia. The Social work education system is divided into two categories: an academic education program and a professional education program. This paper highlights some of the imminent issues that cause concern, such as the search for a theoretical model of social work education and practice suitable for Indonesian society, standardization of curriculum design, teaching and learning, fieldwork and supervision, online education in social work education, accreditation and licensing for social workers. It's important to discuss some issues of concern and the direction in which a strong and sound social work education can be developed.
\end{abstract}

Keywords Social Work, Social Work Education, Curriculum, History

\section{Introduction}

Indonesia is an archipelagic country of 17,508 islands (more than 6,000 of which are inhabited) that stretch along the equator in Southeast Asia. The five major islands are Sumatra, Kalimantan, Java, Sulawesi, and Papua. Based on the National Census 2010, the population of Indonesia is 237.6 million, many of whom are descendants of people from various migrations, creating a diversity of cultures, religions, ethnicities, and languages. The official language of Indonesia is Indonesian (Bahasa Indonesia). It is the language that unifies Indonesia, with its 350 ethnic groups and 750 native languages and dialects. The archipelago's landforms and climate have significantly influenced agriculture, trade, and the formation of the state. Indonesia is divided administratively into provinces and districts. Between 2001 and 2013 the number of provinces expanded from 27 to 34 (Ministry of Domestic Affairs, 2013).

Indonesia proclaimed independence from Japanese colonial rule on August 17, 1945. Since then the country has experienced several profound political developments. Indonesia's founder, President Soekarno, was succeeded by President Soeharto in 1966. A "new order" government was established in 1967, and it was oriented toward direct overall development. In 1997 and 1998 Indonesia went through its worst economic crisis since independence (CBS, 2003). After more than three decades in power, President Soeharto resigned in 1998. The political situation underwent rapid transition. Soeharto's last vice president, B. J. Habibie, succeeded him as president from 1998 to 1999 , and he was followed by Abdurrahman Wahid from 1999 to 2001, and Megawati Soekarnoputri, daughter of President Soekarno, from 2001 to 2004. A historic direct presidential election took place for the first time in October 2004, when President Susilo Bambang Yudoyono came into office and re-elect for second terms 2009-2014.

Indonesia is plagued with a number of fundamental social problems such as poverty and malnutrition, unemployment, children's issues, drug abuse, HIV/AIDS, natural and social disaster, disability and the booming of older people. This problem needs social work intervention by professional social workers.

To understand social work education in Indonesia, we must have knowledge of the history and dynamics of the national education system. The National education is divided into three levels; basic, secondary and higher education. In Indonesia, based on the National Education System Law No. 20 Year 2003, the higher education institution can be in the form of academy, polytechnic, college, institute or university. Higher education is provided by the Ministry of National Education, other Ministries or Government Institutions and by the community or private agencies.

In the National Education System, higher education is divided into two types known as academic education and professional education. Academic education is a higher education based on innovative science and development with more emphasis on quality improvement and a broader science vision. Academic education is usually offered by a college, institute or university. Meanwhile, professional 
education is a higher education that exists to prepare students in the application of specific skills with emphasis on the improvement of competency and work skills or applied science and technology. The latter is offered by an academy, polytechnic, college, institute or university.

Academic education is mostly under the administration of the Ministry of National Education while professional education is generally under the administration of other ministries which excludes the Ministry of Education. The main purpose of Academic education is to produce graduates with academic degrees such as the undergraduate (S1-Bachelor) and postgraduate (S2-Master and S3-PhD) degrees. On the other hand the aim of professional education is to produce graduates with professional labels from diploma (Diploma 1 to IV) to a specialist (Specialist 1 to 2).

The development of social work education in Indonesia has been seen a series of historical moment in which different ideas about goal of social work profession have continue to be debated. Even though there is still no 'National Standard for Social Work Education' include basic curriculum, accreditation, field work system, field work supervision, and also national definition of what is social work should guiding by various universities and colleges and also among stakeholder. Ministry of Research, Technology and Higher Education and Ministry of Social Affair had very important role in the development of social work education for the future. Historical and current situation of social work education in Indonesia have same and in some issue to be different with history and current situation in other countries such Malaysia, Vietnam, Bangladesh and China.

In Malaysia, professional social work was introduced by the British Colonial Administration as early as the 1930s but it was mainly focused on problems of migrant laborers from India and China (Yasas, 1974). It was only after World War II, when social problems of displacement, juvenile delinquency and poverty became more prominent, that a Department of Social Welfare was formerly established in 1946. Social work services were introduced in terms of financial aid for the needy, probation programs for juvenile delinquents, protection homes for women and girls, and residential care for the disabled and the aged. But social work education formally start at University of Malaya in Singapore in 1952 (Yasas, 1974). According Baba (1988) the development of social work education programs in the country also vary from program to program. It appears that social work education program at University of Science Malaysia is the only program which is a member of the IASSW. In terms of social work trained academic staff, many universities still rely on non-trained social work academic staff from other disciplines (Baba, 1992). But during social-economic progress 1985-2000, the situation was changed and social work education in Malaysia develops very past compared within ASEAN countries exclude Philippines.

In Vietnam for example, idea about importance of social work in national development starting in 1986 when began 'doi moi'; a process of economic reform'. But social work education formally start 1995 when the Ministry of Education and Training approved two higher education institutions to teach social work as part of broader social science program (Hugman, Lan, \& Hong, 2007). Social work education in Vietnam today open in other universities without national standard for social work education such as curriculum, academic staff, field work and etc.

Social work education in Bangladesh originated in the Pakistan regime having two key objectives to build professional leadership in solution of acute and large-scale social problems and to criticize the operation of existing social welfare structure in response to various human needs and guide the future development program. An introductory course in social work of three months duration was first started in Bangladesh (then known as East Pakistan) in 1953. After that, in 1955-56 professional education in social work was introduced as a nine-month training course on Community Development and Medical Social Work at Dhaka University. With the completion of the nine-month on-the-job training course under the country's first Urban Community Development Project, the establishment of a school of Social Work under Dhaka University was proposed. Samad and Faruque (2009) state that all the above initiatives were undertaken under the auspices of UN Technical Assistance Program in social service sector and guided by the UN experts namely Dr. J. J. D Moore, Mr. Shawty, Ms. Anana Tooll, Ms. Lucky and Mr. Dumpson.

In China for example, social work education had been in existence in a few universities such as Yanjin University of Nanjing, but during 50s and 60s politic movement seen social work subject service the capitalists, were must aborted from the university curriculum. Social work education and training in China develop very past than other countries, when government took an Open Door Policy in 1978, sociology teaching was resumed and that paved the way to reintroduce social work to higher education (Law \& Gu, 2008). Today, social work education in China rapid expansion when 1988, the Ministry of Education formally approved universities to established social work program, the Ministry of Civil Affairs also took to lead to set up the 'Civil Affairs Social Work Education Research Center' in 1987, and the China Social Worker Association in 1991, and also the China Association of Social Work Education in 1994. Social work education has a unique path of development in China. In the absence of trained social work academics, there was rapid growth of social work programs at all levels of training institutions, including universities under the ambit of the Ministry of Education, provincial and district level universities, and local vocational and technical training institutes. According Law and Gu (2008), there were approximately 30 social work programs established in 1999, mostly under the auspices of the sociology departments of respective universities and nine of them formed an independent Social Work Department. But, in 2006, there were more than 200 institutions across the country providing social work training of various levels. The number is expected to rise. Without explicit government policy 
acknowledging social work as an accredited vocation, the rationale for universities to add social work to their teaching subjects is a pragmatic one (i.e. fulfilling the government's requirement of expanding higher education by increasing the intake of undergraduate students despite the lack of relevant teaching staff and job opportunities for graduates). In Thailand, history and development of social work also unique. Social work (SW) education has been taught in 2 universities in Thailand. Thammasat University (TU) which is the second oldest and public university started this program since 1954 and established the Faculty of Social Administration (FSA). While the Faculty of Social Work and Social Welfare (FSWSW), belonged to a private university called as Hua Chiew Chalermprakiat University (HCU), opened SW program in 1990. Both institutions are quality accredited by the Commission on Higher Education, Ministry of Education (MOE). In actual fact, the first social work training program in Thailand was launched in 1942. It was a one year program and was administrated by the Council of Women Culture in the period of Marshal Pibulsongkram Government. The council offered the Diploma (Certificate) for those who completed the program. The trainees were government servants who worked in the council. Due to lots of difficulties, such as, lacking of appropriate teachers, the program terminated after 3 years of operation.

Development of social work education in Indonesia, Malaysia, Vietnam, Bangladesh, China and Thailand is varied in system, curriculum, field work, academic staff, and government supported. Contribution from expert under United Nation Development Program in early social work education established play important role in development of social work education. Economic progress was correlated with development of social work education in Malaysia and China. Vietnam social work education starting when began economic reform. It is contradictive with Malaysia, China and Vietnam, social work education in Indonesia and Bangladesh not supported by economic progress in their country. Current situation of social work education in Malaysia and China was developed very past; but in Indonesia develop very slowly. The major issues in this context are what direction of social work education in Indonesia and need to reform in the system, curriculum, staff development, field work, and etc.

\section{History of Social Work Education}

Social work education in most countries is offered at college or university level. The major exception is Indonesia, where social work courses are offered not only in universities and colleges but also in secondary schools (Midgley, 1981). Formal social work education in Indonesia starts in secondary level. It's established with decree Ministry of Education: No SK: 24/C, Date: 04-09-1946, the Ministry of Education and established the Sekolah
Pembimbing Kemasyarakatan (SPK) in Solo, Central Java ${ }^{1}$. This is the first social work education at secondary school level and is offered for 4 years. This school established result of collaboration between Minister of Social Affairs with Ministry of Education and Culture to training ministry of social affairs staff both male and female. In year 1950, these schools develop to train in theory and practice and majority of the student is still the ministry of social affairs staff. In 1952, 25 of graduates from this school send by the ministry of social affairs to further study in School voor Maatschapelijk Werk in Netherland. One of the student is $\mathrm{Mr}$ D.Drajat and in the later his teaching in the Basic Social Vocational Training (Kursus Dinas Sosial A (KDSA), a one year short-term course program and the Kursus Dinas Sosial Menengah dan Atas (KSDA) course extends to Kursus Kejuruan Sosial Tingkat Menengah dan Tinggi (KKSMT), a two year training program ${ }^{2}$. This course considered as early formal education and training center to improve the quality of human resource in the ministry of social affair (Sulaiman, 1985: Fahrudin, 1997). The first Director of KDSA is $\mathrm{Mr}$ H.A.Romlie (from 1957-1963). In 1964, these training centers were upgraded to university status under the Ministry of Social Affairs with name Bandung School of Social Welfare which has college university status providing a three-year bachelor's degree and a two- year post-graduate doctorandus.

In the year 1955, SPK also established in Jakarta, and in year 1959, these schools changed its name to "Sekolah Pekerjaan Sosial Atas" (Social Work High School-SPSA) and also established in other part in Indonesia such as in Medan, Palembang, Semarang, Malang, Banjarmasin, and Makasar. In 1976, this school again had a name change to "Sekolah Menengah Pekerjaan Sosial" (Social Work Secondary School-SMPS) and still offered for 4 year. In 1994, the school's name was changed to Sekolah Menengah Kejuruan (SMK) Kesejahteraan Masyarakat (Vocational Secondary School-Community Welfare), and again, based on Ministry of Education and Culture decree number 036/O/1997, date on 7 March 1997, social work program in the schools was merged with other programmes under Sekolah Menengah Kejuruan (Vocational Secondary School) with one of the majors being Social Work/Social Care and requires 3 years of study.

The establishment of the Sekolah Pembimbing Kemasyarakatan (SPK) and Kursus Dinas Sosial Menengah dan Atas (KSDA) is not solely because of the pressure needs skilled human resources for the implementation of the Ministry of Social Affairs task relatively newly formed but also the shape of the response of the two previous surveys of the United Nations International Surveys of Training for Social Work. Documents of Training for Social Work: An International Survey, United Nations publication Sales No:

1 Keputusan Menteri Pendidikan No: 24/C. Tanggal 04-09-1946

2 Generally, in BSSW history public only known KKST, but in formal document Kursus Kejuruan Sosial Tingkat Menengah dan Tinggi. 
1950.IV.11 and Training for Social Work: Second International Survey, United Nations publication Sales No:1955.IV.9 was very clear that the education and training of social work in Indonesia yet. This is a consequence, first, Indonesia is a relatively new independent state and post-independence political turmoil made the leaders when it was not time to think about the need for expert and skilled in the field of social work. The second reason is the countries that once colonized Indonesia such as the Netherlands and Japan did not help prepare a system of social welfare services including preparing trained professionals in social work. Many policies were implemented to expand social work to developing countries especially in the Third World under United Nations. Midgley (1981) note that among the earliest activities of the United Nations in the field of social policy was an international survey of social work training...these survey was designed to determine the extent of and need for social work education throughout the world and although it dealt also with the industrial countries, special attention was paid to the Third World (p.57).

Brigham (1982) noted that in 1981, only 4 universities and colleges have social work programme at bachelors and doctorate levels in Indonesia. These courses were offered by the University of Indonesia, Bandung School of Social Welfare, University of Muhammadiyah Jakarta and Widuri School of Social Work. By the 1990s, more public and private universities offered social work education programme with Social Welfare label. According to Sisworahardjo (1993), only 22 institutions. have social work/social welfare programme that are registered with the Indonesian Association for Social Work Education. By the year 2011, there are 33 universities/colleges offering social work/social welfare program (IASWE, 2012). However, according to Sulaiman (1985), the quantity of social work/social welfare program not drawn the quality of social work education program.

Political, social and economic changes in Indonesia also influenced social work education. After the New Order Regime under General Soeharto, more changes and reforms occurred in and social service delivery models (Fahrudin, 1999). and tsunami disaster in the year 2004 in Indonesia provided the opportunities to the higher education institutions to develop in cooperation with national and international agencies. For example, the State Islamic University in Yogyakarta (this university is under the Ministry of Religious Affair), McGill University and the Canadian International Development Agency (CIDA) and offered Postgraduate Interdisciplinary Islamic Studies focusing on social work without an undergraduate social work programme (Fatimah \& Wildan, 2004).

\section{Challenges and Current Issues of Social Work Education}

There are many issues affecting social work education in Indonesia, however this paper will highlight only a few selected issues that are currently affecting and will continue to affect the development and direction of social work practice in Indonesia. If these issues and challenges are not addressed the status quo will remain and would have adverse effects on the young social worker practitioners specifically and other social workers generally; as well as directly or indirectly affect the welfare of the clients they serve.

Social work education in Indonesia is varied in terms of programme content, teaching method, student admission qualification, duration of study, career outcome and the number of student intake each year (Fahrudin, 1999). According to Brigham (1982), the number of schools of social work is not correlated with a country's size, development level, socio-economic status, cultural factor, colonial history or poverty level. Brigham's study has relevance to the Indonesian social work education system. Social work education in Indonesia is very varied, has undergone a slow development and is still struggling to achieve professional education status relevant to its national development. The major problem with social work education in Indonesia is the education system's struggle to attain a professional standard and curriculum that is relevant to the country's needs (Fahrudin, 2009), also weakness in human resources in social work education especially qualified lecturer and instructor for field work.

Colonization also influenced the development of the social welfare system and social work education. For example, the Malaysian social welfare system and social work education were influenced by the British administration. But in the case of Indonesia, colonization by the Dutch and the Japanese had no impact on its social welfare system and social work education (Fahrudin, 2011; 2009; 2005; 1999). In the beginning social work education in Indonesia was influenced strongly by the American model. Most of the social work curriculum is based on curriculum, approaches and modified models of practice from the United States. The curriculum content is more clinical with use of the problem solving approach and model. In the earlier years, social work experts from the United States such Prof Brigham, Prof Irvin Tebor, Prof Bisno, Prof David Drucker, Prof Mildred Sikema mostly guided and supervised the establishment of the social work education curriculum under the United Nations Development Programme (UNDP). Also, most social work educators who are the pioneers in Indonesia particularly from the Bandung School of Social Welfare such as J. Marsaman, Holil Sulaiman, Irawan Soehartono are graduated from universities in the United States (Sulaiman, 1985). They implemented knowledge and experiences gained from the United States into the Indonesian social work curriculum and training without adaptation and modification to the local context (Personal communication with Holil Sulaiman, 23 December 2015)

\section{Social Work Curriculum}

Historically, social work education in Indonesia accepts and adapts more models from the Western social work 
education. This has relevance to Kendall's (1986) study where some evidence shows that Asian schools are still struggling with the problems of indigenization and the implementation of social development objectives in social work education. There is no serious effort in searching for the core or supplementary social work curriculum that is more relevant to national development. Efforts to change the curriculum patterns in order to increase its relevance is occurring although very slowly. The formulation of the social work education standard and core curriculum relevance to IASSW global standard for social work education and training still pose as major issues. This has relevance to Coulshed (1993) statement that the universal problem in social work curriculum design is on how to include more variety in the subject matter into courses and the issues in applying it into the teaching and learning of social work students and how to integrate methods of teaching and learning that can be applied into social work.

There is no difference in the social work/social welfare education programme in both the public and private universities. For example, students at the Bachelor level at University of Indonesia must take 144 credit hours. It is the same with the required credit hours for students of Diploma IV level at the Bandung School of Social Welfare. Social work education in Indonesia is very varied. The higher education structure being divided into the academic and professional education has implication for the social work education system as these is also divided into two mainstreams. Academic education program is represented by the public and private universities, which have educational program labeled Social Welfare Science programme, eanwhile the professional Social Work education programme is represented by the Bandung School of Social Welfare. In the future, social work education in public and private universities in Indonesia needs to reform the program name in order to align with the naming of social work in the international world. It is also to facilitate the recognition of graduates so that they can work and continue further education in other countries without problems of qualifications and competences. At the same time, the government represented by the Ministry of Research, Technology and Higher Education has the authority to set up university courses to align with clumps of science and global developments. Organization of social work education and social work profession need to be actively involved and to follow guideline from Global Standard for Social Work Education and Training (IASSW, 2014).

\section{Field Work}

In Indonesia, the curriculum and field work system has differences in its academic (university administration) and professional (college) mainstream. The typical curriculum for social work education at the bachelor level is generic social work. The difference of curriculum and field work both academic and professional mainstream is in term of length of field work, supervision, method of evaluation, etc. However, it is contradiction with generic social work education.

For example, fieldwork placement for social work students in the university administration is a compulsory subject for all students. However there is problem in the structure and content of this fieldwork placement where fieldwork is not systematically supervised by a social work educator from the university or by a trained social worker in the respective social welfare agency of placement. Universities providing academic education program in social welfare are more flexible in that there are not strict in their supervision both from university and from the agency. Students do field work without the minimum hours of requirement. Some other colleges offering professional education in social work have a systematic system for fieldwork. Students from such colleges must take the subject with three fieldwork options and the minimum total of 600 hours. This subject consists of three types of fieldwork, which are; Fieldwork I in the agency and community with concurrent placement, Fieldwork II in the community with block placement and Fieldwork III in the agency with block placement. It is in this fieldwork placement that the students are given the opportunity to apply their theoretical knowledge in the practice context. From this fieldwork involvement, students are being taught to acquire basic skills which are necessary for working with an individual, group or community. Generally, the major handicap in fieldwork education in Indonesia is the lack of professionally qualified social workers to take up the supervisory role for students on field placements. Unlike developed countries, Indonesia still lacks a cohort of trained personnel to supervise students in their fieldwork environment. The lack of these trained professionals has invariably burdened the academic staff with the task of supervising students in their field placement as well (Fahrudin, 2004c; Fahrudin 2004d). For improvement the field work system, content and method of supervision, universities/colleges can do a pilot project such as crash program to induct social worker as a field work supervisor then they are given adequate training. The model of university and social service agencies or NGOs relation like this can be developed learning process in social work education.

\section{Student Selection}

The final issue in social work education worthy of mention is the selection mechanism of students. In this case, there is no systematic mechanism for selection of students who enter into social work education in Indonesia. Having the selection criteria in place for entry to any programme or profession has considerable significance for those who are selected or rejected. For those who are selected, this represents entry to the first stage of a professional career and for preparation for this career. This may mean changes in the social status, income, lifestyle and life chances of the candidate, in addition to a membership into the professional community (Fahrudin, 2004d). In public universities they have national student selection mechanism but not specific for selection of social work course. Meanwhile private 
universities, they didn't have standard for selection of social work students.

\section{Standard and Accreditation}

Both in the universities and colleges, social work/social welfare programme are delivered only through regular classes. There is no online education or distance education system. Until now, the accreditation for social work education as well as the licensing for social work practice is not clear and as yet not implemented. Generally, Indonesia has established the BAN-PT-Higher Education Institution National Accreditation Board (Badan Akreditasi Nasional-Perguruan Tinggi) administered by the Ministry of National Education for accreditation of education programme in general in both universities and colleges. Indonesia also has a semi government institution under the administration of the Ministry of Manpower and Transmigration called Badan Nasional Sertifikasi Profesi (BNSP-National Board for Profession Certification). The function of this board is not specific for social work but for all professions and occupations. Because there is no specific standard and accreditation for social work education, it is difficult to ensure the quality of social work education as well as the quality of social work practice. This will pose problems to social work students who want to further their studies overseas and for social work graduates who wish to practice or work in other countries.

\section{Multicultural Education}

Indonesia is a multicultural country and is made up of people from different racial, ethnic, socio-economic, religious and cultural background. The social work education program is challenged in teaching cultural sensitivity to social work students. Issues include how to design and implement a social work curriculum which is relevant to the multicultural society. The main responsibility of social work educators with regards to this issue is to help in the transitional process from a student to a professional social worker; and ensure the physical and academic environment for learning is favourable and provide them with relevant practice knowledge and skills. One of the most important issues facing social work education in Indonesia today is as follows; how can students be taught social work in a way that is personally meaningful to them, directly related to the developmental functions of the country and its own cultural context? If the answer could be given in one word, it would be indigenization. It is necessary to indigenize the teaching methods and teaching materials. In 1987, after the APASWE/IFSW Asia Conference in Jakarta, the Indonesian Association for Social Work Education (IASWE) organized a national workshop on National Social Work Education Curriculum standard in Bandung (Sulaiman, 1987). The result from this workshop is a document on core social work curriculum and the indigenization of teaching material. The debate on Western social work education and indigenization will continue for some time to come.
Indigenization issues some time just for a debate not for action.

\section{Indigenization}

Issues in the development of indigenous social work in Indonesia are related to religion and the local culture. In 2004, the State Islamic University in Yogyakarta jointly opened a new postgraduate programme with McGill University and CIDA. This postgraduate programme is the Master of Arts in Interdisciplinary Islamic Studies with a major in Social Work. In this program, it is interesting to combine Islam as a religion to social work and view it from a secular perspective. However, generally the development of indigenous social work in Indonesia has not been very successful. The curriculum, teaching materials, reference books and fieldwork model are still being adapted from the United States and other country.

As evident after the tsunami disaster in Aceh, social work education and practice in Indonesia has been largely influenced by social workers, volunteers, and international humanitarian organization workers who provided assistance then. The change and awareness of the global environment particularly in relation to the multicultural, globalization, and sustainable development in the country has influenced social work education and practice. However, universities and colleges modify and adapt their programmes according to their perception and interests without direction and guidance from the Indonesia Association for Social Work Education (IPPSI), International Association of Schools of Social Work, APASWE and also from Indonesia higher education authority.

\section{Social Work Distance Education}

An important issue in social work education is distance education. Both in the universities and colleges, social work/social welfare programme are delivered only through regular classes. There is no online education or distance education system. Distance education in social work is not driven by technology but by the profession's obligation to educate social workers in a way that will ensure their ability to fulfill needed services to persons and communities effectively (Abels, 2005). In reality, Indonesia is the world's largest archipelago and is estimated to have about eighteen thousand islands. Therefore, distance education in social work provides an ideal way of bringing improved educational opportunities to its rural and island areas especially for individuals keen to become social workers and who would otherwise be left out due to its diverse economic and geographical constraints. Indonesia has 33 schools of social work and the majorities are found on Java Island. Distance education in social work is compulsory for Indonesia to promote social access, equality and social justice for everyone. Distance education in social work in this context not only provides a medium for the teaching of social work; it also helps in fulfilling social work commitment to equality and social justice. 


\section{Conclusions}

The history of social work education in Indonesia started after independence. History, development and current situation of social work education is very varied between a country to other country. Colonization not significant influenced the development of the social welfare system and social work education in Indonesia. The development of social work education and the social work profession is still struggling to attain maturity as a profession. Social work education needs a new direction in order to achieve international standard in curriculum, field work, student selection, indigenization, multicultural perspective, and distance education. The future direction of social work education in Indonesia will not be successful without strategic alliance and cooperation from higher learning institutions that offer social work education program and support by government. Many stakeholders especially government institution, school of social association and national association of social workers need to play their role and give their support in order to promote, improve and enhance the quality of social work education and practice in Indonesia. Quality of social work and practice need specific regulation from government, and the quality assurance in social work education and practice is very important to protect the social work profession in the future, and to ensure that the local graduates from social work program become qualified and competent social workers.

\section{REFERENCES}

Abels, P. (2005). The way to distance education. In Paul Abels (Ed), Distance education in social work: Planning, teaching and learning. New York: Springer Publishing Company, Inc.

Baba, I. (1998). The need for professionalism in social work: In the case of Malaysia. Paper presented at Advancing Social Work Education. Kota Samarahan: Universiti Malaysia Sarawak.

Baba, I. (1992).Social Work- An Effort towards building a caring society. In Cho Kah Sin \& Ismail Muhd Salleh, Caring society: Emerging issues and future direction. Kuala Lumpur:ISIS Malaysia.

Central Bureau of Statistics. (2010). National Population Census Report. Jakarta: CBS

Fahrudin, A. (2009). Future Challenges and Direction of Social Work Education and Practice In Indonesia. Proceeding of Seoul International Conference on Social Work (Deans Conference) "Social work Education and Practice Development in the Asia and Pacific Region. Seoul Korea, 15-18 April 2009. Organized by Korean Association of Social Workers, Korean Council on Social Welfare Education, and APASWE.

Fahrudin, A. (2005a). Regionalization of Social Work Curriculum in AFTA Era. Proceding of Indonesian-Malaysian Cultural Symposium (SKIM IX). Organized by Padjajaran University and National University of Malaysia, Bandung, 10-12 May 2005 .
Fahrudin, A. (2005b). Mainstreaming social development in national policy and program. Paper presented at International Conference on Social Development, Jakarta: State Islamic University.

Fahrudin, A. (2004a). Kurikulum Pendidikan Pekerjaan Sosial. Jurnal Penelitian Permasalahan Kesejahteraan Sosial, Vol. 9 No. 1 Mac 2004 (ISSN: 1410-0355).

Fahrudin, A. (2004b). Social work education based competence training. Paper presented at National workshop on social work education. Bandung: Bandung School of Social Welfare.

Fahrudin, A. (2004c). Global standard in social work education and critic to social work education curriculum in Indonesia. Paper presented at International Seminar on Social Work Education Curriculum Development, Joint organized by Bandung School of Social Welfare and La Trobe University, Australia.

Fahrudin, A. (2004d). Pendidikan dan latihan pekerjaan sosial berbasis kompetensi. Makalah disajikan dalam Seminar Pendidikan dan Pelatihan Berbasis Komptensi. Bandung: College of Social Welfare.

Fahrudin, A. (2003). Pendidikan dan latihan kerja sosial dan piawaian praktis kerja sosial di Malaysia (Social work education and training and social work practice standard in Malaysia). Buletin Psikologi, Bil. 8/Tahun 2003. Kota Kinabalu: Sekolah Psikologi dan Kerja Sosial, Universiti Malaysia Sabah.

Fahrudin, A. (2002). Direction for social work education. Kota Kinabalu: School of Psychology and Social Work, Universiti Malaysia Sabah.

Fahrudin, A \& Abdul Halim Othman. (2000). Social Work Education in Universiti Malaysia Sabah: A social work curriculum structure at bachelor level. Paper presented at Round table conference on Social Work Education in Malaysia, 10-12 September 2000, Penang: Universiti Sains Malaysia.

Fahrudin, A. (1999a). Kertas kerja penawaran program BSW, MSW dan DSW di Universiti Malaysia Sabah (Proposal for BSW, MSW and DSW program at Universiti Malaysia Sabah). Kota Kinabalu: School of Psychology and Social Work. Universiti Malaysia Sabah.

Fahrudin, A. (1999b). Komitmen profesional dikalangan pelajar kerja sosial di Indonesia (Professional commitment among social work students' in Indonesia). PhD Thesis (Social Work), Unpublished. Penang: Institute of Postgraduate Studies, Universiti Sains Malaysia.

Fahrudin, A. (1997). Pendidikan tinggi pekerjaan sosial: Sejarah, agenda masalah dan kegayutannya dengan pembangunan nasional (Social work higher education: A history, problems agenda and relevance with nasional development). Dalam Prosiding Seminar Ilmiah Perhimpunan Pelajar Indonesia (PPI) se - Malaysia. Penang: Perhimpunan Pelajar Indonesia, Universiti Sains Malaysia.

Brigham, T. M. (1982). Social work education pattern in five developing countries: relevance of US Microsystems model. Journal of Education for Social Work, Vol. 18 (12), 21-26.

Coulshed, V. (1993). Adult Learning: Implications for Teaching in Social Work Education. British Journal of Social Work, Vol. 23., $1-13$.

Hammoud, H., R. (1988). Social Work Education in Developing Countries: Issues and Problems in Undergraduate Curricula. International Social Work, Vol. 31., hal.195-210.

Hugman, R., Lan, N.T.T \& Hong, N.T. (2007). Developing social 
work in Vietnam. International Social Work, 50(2), 197-211.

Law, K.C.A. 7 Gu, J.X. (2008). Social work education in Mainland China: Development and Issues. Asian Social Work and Policy Review, 2, 1-12

Midgley, J. (1981). Professional Imperialism: Social Work in the Third World. London: Heinemann.

Ministry of Domestic Affairs. (2010). List of provinces, districts, cities, and sub districts in Indonesia. Retrieved 10 June 2013 from http://www.depdagri.go.id/media/filemanager/201 3/01/29/0//0.induk kec.pdf

Moore, J. J. O. (1958), The Report and the Prospect from Which It Arose: A Tentative and Unpublished Report, Prepared for the Government of Pakistan, Dhaka.

Mongkolnchaiarunya, J. (2009). Social Work Education and Profession in Thailand: Sunrise or Sunset. Paper presented at the Seoul International Social Work Conference - Dean's Forum: „Social Work Education and Practice Development in Asia Pacific Region" in Seoul, South Korea during 15-18 April, 2009. The conference is jointly organized by the Asia Pacific Association for
Social Work Education (APASWE), Korean Council on Social Welfare Education (KCSWE) and Korean Association of Social Workers (KASW).

Samad, M. \& Faruque, C.J. (2009). Development of social work education in Bangladesh and Need for international Cooperation. Proceeding of Seoul International Conference on Social Work (Deans Conference) "Social Work Education and Practice Development in the Asia and Pacific Region. Seoul Korea, 15-18 April 2009. Organized by Korean Association of Social Workers, Korean Council on Social Welfare Education, and APASWE.

Sisworahardjo, S. (1993). School Members of the Indonesian Association for Social Work Education, Asian Pacific Journal of Social Work, Vol.3 (1).

Sulaiman, H. (1985). Pemikiran Ke Arah Peningkatan dan Pengembangan Pendidikan Pekerjaan Sosial di Indonesia. Bandung: Sekolah Tinggi Kesejahteraan Sosial.

Yasas, F. M. (1974). Report to the government of Malaysia on the establishment of a professional course in social work and community development training at the bachelor's level at the Universiti Sains Malaysia. Bangkok: ESCAP. 